\title{
INHERITED AGGLOMERATION EFFECTS IN HEDGE FUND SPAWNS*
}

\author{
Rui J. P. de Figueiredo Jr. \\ University of California Berkeley \\ Haas School of Business \\ rui@haas.berkeley.edu
}

\author{
Philipp Meyer-Doyle \\ The Wharton School \\ University of Pennsylvania \\ philippm@wharton.upenn.edu
}

\author{
Evan Rawley \\ Columbia University \\ Columbia Business School \\ erawley@columbia.edu
}

\begin{abstract}
This paper studies inherited agglomeration effects, which we define as human capital that managers acquire while working in an industry hub that may be transferred to a spinoff. We test for inherited agglomeration effects in the hedge fund industry and find that hedge fund managers who previously worked in New York and London outperform their peers by about one percent per year. The results are driven by managers who worked in investment management positions previously, and are at least as large as traditional agglomeration effects that arise from being located in an industry hub contemporaneously. The evidence suggests that inherited agglomeration effects are an important, but as yet overlooked, factor influencing the performance of new firms.
\end{abstract}

\section{INTRODUCTION}

Entrepreneurial spawning, the founding of new companies by employees of incumbent ("parent") firms, is a key driver of entrepreneurial activity in the economy (Bhide, 2000), and an important branch of the literature has shed light on the phenomena and its antecedents (Agarwal et al., 2004; Gompers, Lerner and Scharfstein, 2005). While it is well established that the resources an entrepreneur brings to a spawn at founding impact the performance of the new venture (Stinchcombe 1965; Boeker, 1988), and that new firms are shaped by the experience entrepreneurs gain through prior employment (e.g., Dencker, Gruber and Shah, 2009), there is still much we do not know about how managers' prior employment experience influences the performance of entrepreneurial spawns. Yet understanding why some new firms thrive while others fail is of great importance for scholars and practitioners alike. Indeed, Helfat and

\footnotetext{
*We thank Rajshree Agarwal, Raffi Amit, Charles Baden-Fuller, Iwan Barankay, Marcella Barnhart, Olivier Chatain, Ronnie Chatterji, Gary Dushnitsky, Simone Ferriani, David Hsu, Sascha Klamp, Joris Knoben, Ethan Mollick, Chris Rider, Lori Rosenkopf, Harbir Singh, MB Sarkar, and participants at the ACAC, the 2010 EGOS conference, the 2010 DRUID conference, the 2010 Strategic Management Society conference, and the 2010 and 2011 Academy of Management conferences for thoughtful comments and suggestions. We also thank Anita McGahan (the editor) and two anonymous reviewers for their helpful comments. Maeve Flynn, Elaine Ho, Bryan Hsu, Nicole Wang and Austin Winger provided outstanding research assistance. We are grateful to the Wharton Entrepreneurship and Family Business Research Centre at CERT, the Kauffman Foundation, and the Rodney L. White Center for Financial Research at The Wharton School for their generous financial support.
} 
Lieberman (2002) write that "surprisingly little is known about [the birth of capabilities and resources within organizations], despite its centrality to the understanding of firm evolution" (p.725). More recently Chatterji (2009) highlights the need for more research on how parent firm characteristics influence the performance of spawns, noting "it would be interesting to attempt to further differentiate between ... parent firms ... (as) there is more work to be done in comparing the performance of spawns based on the characteristics of their parent firm" (p.202). This observation has been echoed by Fern, Cardinal and O'Neil (2011) who point out that, "few studies have explored how pre-founding experience influences ... a new venture's ... performance."

This paper examines an intuitive, but largely overlooked, channel through which performance effects are transferred from parent firms to new firms: inherited agglomeration effects - the economic benefits that accrue to managers while working at a parent firm in an industry hub that can be subsequently transferred to a spinoff, regardless of where the new venture is located. ${ }^{1}$ We use the term "inherited agglomeration effects" to emphasize that the economic benefits of agglomeration are appropriated and transmitted from parent firms in industry hubs via managers who leave to manage spawns and to distinguish between this effect and traditional agglomeration effects. ${ }^{2}$ While there is a large and prominent literature examining how a new venture's location in an industry hub influences its performance (e.g., Audretsch and Feldman, 1996; Stuart and Sorenson, 2003), there is little research on how parent firm agglomeration influences new venture performance. Yet, given the broad agreement in the literature that parent firms influence spawn performance, and that agglomeration effects influence parent firm capabilities and resources, it would seem to be of great importance to

\footnotetext{
${ }^{1}$ We use the terms spawn and spinoff interchangeably throughout this paper.

${ }^{2}$ Traditional agglomeration effects arise from being physically located in an industry hub concurrently.
} 
understand how inherited agglomeration effects contribute to new venture performance. In this paper, we lay out the conceptual basis for inherited agglomeration effects and test for evidence that such effects exist and are moderated by relevant experience. In doing so, we develop a novel lens for understanding how new venture performance is influenced by the characteristics of managers' parent firms. Furthermore, inherited agglomeration effects also help to explain how human capital diffuses outside of industry hubs into peripheral regions through entrepreneurial spawning and employee mobility.

Our conceptual approach integrates research on entrepreneurial spawning and agglomeration to examine how inherited agglomeration effects increase the commercial value of a nascent entrepreneur's human capital when they are still an employee of an incumbent firm. Specifically, we propose that when a firm in an industry hub benefits from agglomeration effects, employees of the firm will develop valuable human capital that may be subsequently transmitted to new ventures. ${ }^{3}$

We test the implications of inherited agglomeration effects in the context of the global hedge fund industry. The hedge fund industry is a good setting for a study of inherited agglomeration effects for three reasons. First, the industry has had high rates of new venture formation over the last three decades, which provides us with a wealth of new ventures to study. Second, as with many professional services firms, hedge funds are knowledge-intensive businesses; yet, there is very limited formal intellectual property protection in the industry. Thus, it is straightforward to suppose that an economically meaningful amount of a manager's human capital acquired at a closely related parent firm is general and transferable to a hedge fund. Finally, hedge fund performance can be measured with a relatively high degree of accuracy, even

\footnotetext{
${ }^{3}$ For ease of exposition we define human capital broadly to include social capital. Later, we distinguish between the knowledge and social capital components of human capital empirically.
} 
for very young firms, which provides us with a more precise measure of spawn performance than firm survival (Agarwal et al., 2004) and pre-money valuation (Chatterji, 2009).

We find that hedge fund managers who were previously employed by parent firms located in financial services industry hubs-New York or London-outperform their peers by about one percent per year, net of fees, an effect that is at least as large as traditional contemporaneous agglomeration effects. In other words, we find that the location where a future hedge fund manager spends her early career is at least as important as where she locates her hedge fund. While our data does not allow us to control directly for managers' unobservable ability, the results are robust to the inclusion of fixed effects for the major ("bulge bracket") investment banks and to controls for manager selection into New York and London employment, based on several important observable dimensions of parent firms, hedge funds and managers. Interestingly, the inherited agglomeration effect appears to stem most strongly from managers whose prior employment was in investment management, the job type most closely related to hedge fund management.

We also distinguish between two potential mechanisms underlying inherited agglomeration effects: knowledge-based effects and social capital effects. Knowledge-based inherited agglomeration effects arise if individuals who work at the center of an industry are exposed to valuable ideas and techniques that others are less likely to observe (Glaeser et al., 1992; Bell and Zaheer, 2007). Social capital-based inherited agglomeration effects arise when an individual working at a firm in an industry hub is exposed to customers and suppliers who may be critical to the success of a new venture (Saxenian 1994a, 1994b; Hellmann, 2007). When individuals who have worked in industry hubs leave their parent firms to lead an entrepreneurial spawn, they take their unique knowledge and contacts with them, and consequently the commercial value of their 
human and social capital becomes part of the new firm's initial resource base. Thus, both mechanisms potentially can drive inherited agglomeration effects. We design an empirical test that helps distinguish between knowledge-based effects and social capital effects. The results show that inherited agglomeration effects are strongest in hedge funds engaged in direct investment activities, which suggests that inherited agglomeration effects are driven by the transference of technical trading knowledge in the hedge fund industry.

\section{CONCEPTUAL DEVELOPMENT}

In this section we integrate theory from the entrepreneurial spawning literature and the agglomeration economics literature to develop insight into how new firms are influenced by managers' prior experiences. Our cross-disciplinary approach draws on sociology, economics and management research to explicate how a deeper consideration of knowledge transference from agglomerated industry hubs can be a powerful complement to the extant entrepreneurial spawning literature. We begin by exploring the logic behind each of the two literatures and show how the assumptions behind the entrepreneurial spawning literature imply that agglomeration effects influence a firm's founding conditions, and thereby its subsequent performance. Once entrepreneurial spawning and agglomeration effects are taken together our key insight becomes apparent: the benefits of agglomeration can be captured and transmitted by managers when they transition to a new venture. In other words, the theories imply an interactive effect between spatial agglomeration and temporal spawning effects: agglomeration effects can be inherited by the spawn, possibly to even greater effect than contemporaneous agglomeration effects.

\section{Entrepreneurial spawning}

The powerful observation that successful entrepreneurs tend to come from good parent firms 
(Burton, Sorenson and Beckman, 2002) points to the idea that valuable economic resources are often transferred from parent firms to spawns through the conduit of the entrepreneur. Given that firms are fundamentally shaped by their founding conditions (Stinchcombe 1965; Boeker 1988, 1989; Johnson, 2007), the idea that parent firm quality matters is compelling; but, if coming from good stock is important for new ventures, it raises a fundamental question about which parent firm characteristics impact spawn performance.

The extant literature on entrepreneurial spawning evaluates three sources of potential parent firm characteristics that might influence spawn performance: access to technical knowledge, access to social capital and access to managerial systems. By providing a platform for managers to accumulate relevant technical knowledge, parent firms provide a crucial training ground for nascent entrepreneurs who strike out into related ventures (Toole and Czarnitzki, 2009; Elfenbein, Hamilton and Zenger, 2010). For example, spawns in the semiconductor and disk drive industries exploited technological knowledge gained through managers' previous employers to outperform firms that entered from outside the industry (Eisenhardt and Schoonhoven, 1990; Agarwal et al., 2004; Franco and Filson, 2006), and Gruber, MacMillan and Thompson (2008) find that serial entrepreneurs are able to navigate alternative markets for new technologies more effectively due to their prior experiences with related technologies.

Since parent firms provide a platform for employees to develop social ties, social capital can also be transferred between parent firms and spawns, which may facilitate successful entrepreneurship (Gulati and Gargiulo 1999, Gulati and Higgins 2003). For example, Phillips (2002) finds evidence that social capital is transferred between parent and spawns among Silicon Valley law firms, and Florin, Lubatkin and Schulze (2003) show that an entrepreneur's social capital is major determinant of new venture performance. 
Besides technical knowledge and social capital, parent firms also impact spawns by influencing their managerial systems. For example, Cardinal, Sitkin and Long (2004) show how founding conditions influence the control structures of a new short-haul moving company, and Chatterji (2009) finds evidence that non-technical knowledge, like managerial know-how, influences spawn performance in the medical device industry.

Thus, the literature on entrepreneurial spawning makes clear that when managers are able to increase their human capital by appropriating technical knowledge, social capital and knowledge of managerial systems from parent firms, those managers are more likely to be successful as entrepreneurs. While the extant literature demonstrates that prior employment influences the human capital of nascent entrepreneurs, the origins of parent firms' resources - the technical and managerial knowledge embedded in the firm and the position of the firm's employees in crucial social networks - from which the entrepreneur appropriates human capital are less well understood. This paper builds on the idea that human capital is transferable from a parent firm to a spawn, and extends the literature on spawning by examining how the location of an entrepreneur's parent firm in an industry hub can be an important driver of spawn performance via the influence of agglomeration effects on the entrepreneur's human capital.

\section{Agglomeration effects}

Marshall's (1920) seminal work on agglomeration proposes three potential reasons why certain industries tend to cluster in localized areas: (i) access to knowledge spillovers; (ii) access to thick labor markets; and (iii) better access to "implements and materials" from suppliers, where all three benefits of agglomeration are due to reduced costs of acquiring ideas, or factor inputs, due to physical proximity.

Recent scholarly work focused on cluster formation and the performance of firms within 
clusters has generated a wealth of evidence in support of the three Marshallian (1920) factors.

For example, Braun and MacDonald's (1982) pioneering work on the rise of the semiconductor industry, discusses how the benefits of knowledge spillovers accrued to firms located in Silicon valley through individual worker's social networks, writing on pp.128-129:

The advantages of one semiconductor company gains from the proximity of others are considerable. In such a highly competitive industry, it is vital to keep abreast of the latest technology and commercial developments. . . . The concentration of semiconductor companies in Silicon Valley provides excellent conditions for the transfer of knowledge. The industry is founded on expertise and survives by replenishing this expertise with the help of individuals possessing the latest, appropriate knowledge. Whether this is achieved by an informal chat on the golf course between employees of different firms, or by hiring an expert from another semiconductor company, the transfer of knowledge must always be more easily accomplished when firms are as close together as they are in the Santa Clara Valley. Friendships are more readily made among people in the same business in regular contact with each other, and a move to a new job is often much more attractive if it does not mean moving house, changing the children's schools and finding new friends. So important is contact between individual experts seen to be in this industry that the Wagon Wheel Bar at the corner of Whisman Road and Middlefield Avenue in Silicon Valley has been spoken of-not completely in jest-as the fountainhead of the semiconductor industry.

Support for the idea that knowledge spillovers underlie agglomeration effects also comes from a series of large sample empirical papers. Jaffe, Trajtenberg and Henderson (1993) show that patent citations tend to cluster locally, suggesting that knowledge remains tied to specific geographies. Klepper and Sleeper (2005) and Klepper (2007) document that spawns, particularly knowledge-driven spawns in innovative industries, tend to locate close to their parents, suggesting that knowledge spillovers tend to create and reinforce agglomeration effects. ${ }^{4}$ To the extent that the unique knowledge workers gain from working in an industry hub is not firmspecific, it would seem plausible, and even likely, that they would transfer that unique knowledge to their new firm when they changed jobs.

The benefit of labor pooling is, perhaps, the most intuitive of the three agglomeration factors. Marshall (1920) describes how risk reduction from concentrating employers and employees

\footnotetext{
${ }^{4}$ Berchicci, King and Tucci (2011) find that many, but not all, spawns choose to locate near their parent firms. In particular, spawns that enter unrelated markets, or those targeting less advanced technological positions, tend to locate further afield.
} 
facilitated specialization, writing:

[A] localized industry gains a great advantage from the fact that it offers a constant market for skill. Employers are apt to resort to any place where they are likely to find a good choice of workers with the special skill which they require; while men seeking employment naturally go to places where there are many employers who need such skill as theirs and where therefore it is likely to find a good market. The owner of an isolated factory, even if he has access to a plentiful supply of general labour, is often put to great shifts for want of some special skilled labour; and a skilled workman, when thrown out of employment in it, has no easy refuge. (Ch. 4, Section 3).

Modern scholars have emphasized the related idea that specialization of the labor pool improves the matching of jobs and skills between workers and firms (Helsley and Strange, 1990). While much of the early evidence in support of Marshall's (1920) thick labor markets hypothesis was somewhat indirect, recent establishment-level data have borne out this effect as well (Dahl and Klepper, 2008; Ellison, Glaeser and Kerr, 2010). As with knowledge spillovers, if the unique human capital developed due to thick labor markets is not parent-firm specific, labor pooling could plausibly form the basis for inherited agglomeration effects.

Marshall's (1920) third source of agglomeration effects, better access to intermediary inputs, has also received considerable attention at least since Stigler (1951) argued that firms can take advantage of the division of labor in certain functions by outsourcing specialized functions to "auxiliary" suppliers who "must operate in intimate cooperation and seldom do so efficiently at a distance" (p.192). Saxenian (1994a) vividly portrays the importance of such auxiliary suppliers to new ventures in an in-depth comparative study of Silicon Valley firms and firms along Route 128 in Massachusetts, describing how start-ups flourish when they are more centrally embedded in the industry's customers, supplier and support networks. Stuart and Sorenson (2003) provide large sample empirical evidence for the third Marshallian (1920) source of agglomeration benefits, finding that better access to venture capital is a crucial reason why the biotechnology industry clusters in Silicon Valley. Workers who are more heavily exposed to intermediaries, therefore, gain access to a valuable social network that they can take with them to other firms if 
and when they change jobs.

\section{Inherited agglomeration effects}

The agglomeration literature demonstrates that firms located in industry hubs are privy to unique economic benefits. While the economic benefits associated with agglomeration can be a crucial source of competitive advantage for the firm, less is known about whether managers, within firms, can appropriate the benefits of agglomeration in the form of generalized human capital and transfer those resources to new ventures. Yet, the literature on entrepreneurial spawning suggests that parent firm resources-technical knowledge, social capital and managerial systems - are potentially transferable to spawns, and can have a meaningful impact on spawn performance. Because agglomerated managers are afforded novel opportunities and are more likely to be exposed to ideas and contacts, it seems natural to ask whether the benefits of agglomeration can impact a manager's generalized human capital, and whether this generalized human capital may be transferred between a parent firm and a spawn when a manager leaves the parent firm to join a new venture. In other words, this paper takes seriously both agglomeration effects and the idea that economically valuable resources are transferred from parent firms to new ventures when a manager transitions from employment to entrepreneurship. If both entrepreneurial spawning and agglomeration effects are valid it follows that an agglomerated parent firm should impact the performance of its spawns.

When managers work in industry hubs, they are exposed to valuable knowledge, information, ideas and people that managers on the periphery of the industry are less likely to encounter. And when managers leave to found and lead new ventures, the unique access to such drivers of human capital that geographic proximity provides gives them a competitive edge over their peers who work outside of industry hubs. While managers outside of industry hubs also accumulate 
human capital through experience managers within agglomerated environments will tend to acquire more human capital, ceteris paribus. Because generalized human capital can be transferred by a manager when she joins a new firm, including human capital gained due to agglomeration effects, we expect that spawns will inherit agglomeration benefits from their parent firms, and, therefore, will outperform ventures led by managers from outside the industry hubs. We summarize this proposition as:

\section{Hypothesis 1: New ventures will perform better when their principal managers} were previously employed by parent firms located in the relevant industry's geographical hub.

While much of the literature on agglomeration effects in entrepreneurial firms has focused on traditional agglomeration effects, or benefits that accrue to start-ups when they locate in an industry hub, two papers have touched upon inherited agglomeration effects. Klepper and Sleeper (2005) show that agglomeration effects moderate knowledge transference between parent firms and their spawns in the laser industry, which suggests that agglomeration effects can be transmitted between firms. ${ }^{5}$ Gompers, Lerner and Scharfstein (2005) study founders of venture capital-backed firms, showing that individuals who work for entrepreneurial parent firms located in industry hubs are exposed to suppliers, customers and venture capitalists, gaining entrepreneurial skills during their employment, thereby equipping them for founding of their own businesses. While the extant research suggests that agglomeration effects are inheritable, neither paper examines how inherited agglomeration effects influence spawn performance.

In principle, inherited agglomeration effects could obtain via a manager who worked for any firm subject to traditional agglomeration effects in an industry's geographical hub prior to

\footnotetext{
${ }^{5}$ For a related argument see Agarwal, Audretsch and Sarkar (2007).
} 
joining a new venture. However, the literature suggests that some forms of prior employment will be more valuable than others. In particular, one should expect that a new venture will benefit more when a manager's previous job was more closely related to the new venture's operations because managers working in closely related functions will bring more relevant human capital to the new venture (Aldrich, 1999). Therefore, our second hypothesis is:

\section{Hypothesis 2: Inherited agglomeration effects will be greater when a manager's}

pre-founding experience is more closely related to a new venture's operations.

\section{EMPIRICAL CONTEXT: THE HEDGE FUND INDUSTRY}

We test our hypotheses in the context of the global hedge fund industry. Hedge funds are private investment vehicles that raise capital from high net worth individuals and institutional investors to exploit investment opportunities. As private investment vehicles, hedge funds are not subject to the same regulations that govern mutual funds, giving them more investment flexibility. However, private investment vehicles are not allowed to market themselves to the general public. We exploit the fact that hedge funds report a substantial amount of information about their managers and performance as an indirect marketing tool, and use this information to analyze how the location of hedge fund managers' previous employers influences the post-founding performance of hedge fund spawns.

The hedge fund industry emerged as an important sector of the financial services industry in the 1980s, though the first hedge fund was founded in 1949 by Alfred W. Jones. The industry has subsequently undergone rapid expansion, with compound annual growth in assets under management above 15 percent to approximately $\$ 1.7$ trillion in 2010 (Hedge Fund Research, 2010). It is particularly noteworthy that the hedge fund sector has witnessed significant 
entrepreneurial activity over the past three decades: our estimates, based on industry data and discussions with hedge fund managers, suggest that at least 10,000-12,000 hedge fund firms have been founded since 1978 .

Part of the reason for the remarkable number of new ventures formed in the hedge fund industry is undoubtedly the lack of intellectual property protections over investment strategies, which allows individuals to appropriate knowledge applicable to hedge funds while working at a parent firm involved in trading, investing, wealth management and/or risk management. For example, traders at Goldman Sach's risk arbitrage desk, famously led by Robert Rubin, spawned Farallon, TPG-Axon, Eton Park, Taconic, Och Ziff, and Perry, amongst others. ${ }^{6}$ Thus, our emphasis on a manager's opportunity to learn and network while an employee of a parent firm in New York or London as a key mechanism behind the appropriation (and subsequent transference) of agglomeration effects seems warranted.

Of course, not all knowledge an employee gains at a parent firm is transferable, even in a service firm with limited intellectual property protections. For example, Groysberg, Lee and Nanda (2008) find that when star security analysts move to a new firm their external ranking typically declines, suggesting that when firm-specific (or team-specific) knowledge is a crucial input into performance, valuable knowledge may not be readily transferable across firms (i.e., without a "lift out"). While our context is broadly similar to Groysberg, et al (2008), we examine cross-sectional performance instead of within-person performance. The former can reveal inherited agglomerated effects even if a significant component of the knowledge mangers gained at their parent firm is firm-specific. Indeed, as long as a manager in parent firms in New York and London acquires non-zero amounts of generalized human capital applicable to hedge

\footnotetext{
${ }^{6}$ Other examples include Julian Robertson's Tiger Management Corporation, which has spawned a large number of "Tiger Cubs", including Maverick, Lone Pine, Touradji, Shumway, Lone Pine, and Millgate, amongst others.
} 
fund management, the hedge fund they found/join should be subject to inherited agglomeration effects. And, if a New York or London manager's generalized human capital is significantly larger than the amount acquired by managers working outside of New York and London, the empirical evidence will support inherited agglomeration effects. Thus, even in the presence of substantial parent-firm-specific human capital one could still expect to find inherited agglomeration effects.

Aside from the ability to appropriate generalized knowledge of hedge fund operations and strategy, and intrinsic factors such as more autonomy and flexibility, a key driver for individuals leaving their current jobs to found and manage hedge funds is the attractiveness of the external environment; some hedge fund managers are amongst the most highly remunerated professionals in the world. Given the lack of secure intellectual property and the attractiveness of the external environment for nascent hedge fund entrepreneurs, individuals with industry knowledge pertinent to hedge fund management tend to explore ideas through external ventures. And indeed the hedge fund industry is remarkably entrepreneurial, which makes our setting a particularly interesting and important context in which to study inherited agglomeration effects. Moreover, given the knowledge intensity and lack of intellectual property protection, the hedge fund sector appears representative of many other service sectors in the economy.

Broadly, hedge funds are classified into five broad investment styles: "macro funds" invest in financial securities based on global macro-economic trends; "equity long/short funds" invest in equities just as a mutual fund might do, but also engage in short selling when they believe a firm is overvalued; "event-driven funds" invest in financial securities based on corporate events; "relative value funds" exploit securities mispricing; and "fund-of-funds" invest in other hedge funds. However, within each investment style, a number of (often overlapping) trading strategies 
exist, which dampens the importance of differences between firm's stated trading strategies.

Hedge fund firms derive their revenue from management and incentive fees. Management fees are annual asset management fees, based on the net asset value of the assets under management (AUM). The typical management fee, in our sample period, was between 1-2 percent of AUM. Incentive fees entitle the hedge fund firm to a percentage of the achieved investment return, usually subject to high water marks (i.e., no incentive fees are paid until an investor's net asset value exceeds their initial investment). Typically, incentive fees are 15-20 percent of gross returns. In our analysis, we focus on hedge fund performance as reported to their investors. In other words, we analyze returns net of management and incentive fees, rather than attempting to calculate returns to the hedge fund managers themselves. While estimating returns to managers would also be interesting, it would require additional assumptions about investment timing, high water marks and cost structure. Because we do not observe these factors, we confine ourselves to analyzing a firm's performance to its investors.

\section{DATA AND EMPIRICAL DESIGN}

\section{Sample construction}

Data on hedge fund performance, location, size and inception date were obtained by combining the two most extensive and widely used hedge fund databases: Lipper-TASS ("TASS") and Hedge Fund Research (HFR). The data sets include data on over 12,000 individual funds from 3,113 hedge fund firms during the period 1978 to 2006 . Though the datasets are self-reported, they are widely believed to be broadly representative of the global hedge fund industry. ${ }^{7}$ To the TASS and HFR data, we add hand-collected biographical information about the top two hedge funds managers in 684 hedge fund firms from Barclays's 2004 second quarter MARhedge

\footnotetext{
${ }^{7}$ While the TASS dataset is free of survivorship bias, we run our main tests on a pooled sample of TASS and HFR. The results are robust to dropping the firms that are listed in HFR only.
} 
database, including manager name, educational history and previous two employers. ${ }^{8}$ MARhedge does not track defunct funds, but we verified that the MARhedge data was drawn from a statistically equivalent pool of hedge funds as the TASS and HFR datasets by comparing the means of the common variables. We then merged the MARhedge data with the TASS and HFR datasets, which resulted in 1,058 fund-manager pairs with complete information on hedge fund performance and previous employer location.

In order to conduct the empirical tests with meaningful controls on previous employer characteristics, we restricted the test sample to include only job spells with previous employers that were listed on public stock exchanges in the United States and United Kingdom between 1978-2007 including NYSE, NASDAQ, AMEX and the LSE. The resulting data set consists of 658 hedge jobs spells from 548 hedge fund managers at 414 hedge funds that were spawned from 96 unique previous employers. Table 1 shows the characteristics of the 25 most prolific parent firms in our sample. ${ }^{9}$

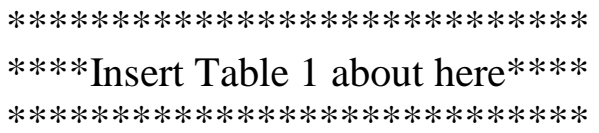

\section{The information ratio}

We use firms' information ratios $(I R)$ as our dependent variable, which measures performance net of systematic risk exposure per unit of idiosyncratic risk. To obtain the information ratio, we estimate abnormal returns as the difference between fund $i$ 's actual return fund at time $t$ and the fund's expected return, using equation (1):

\footnotetext{
${ }^{8}$ Two research assistants independently recorded manager name, previous employer name and education from biographies provided in paragraph form from MARHedge (2004 Q2). For the previous employers the two coders' entries agreed in $84 \%$ of the cases; for the education coding, the coders agreed in $93 \%$ of the cases and Perreault and Leigh's reliability index (1989) was 0.96, suggesting that the coding was highly reliable. Discrepancies were resolved on a case-by-case basis by the two research assistants working independently.

${ }^{9}$ Many, but not all, of the hedge fund managers in our sample were founders. We show that the results are robust to restricting the dataset to founders only (see Table 5 and the associated discussion below).
} 


$$
R_{i t}=a_{i}+R_{f t}+\boldsymbol{X}_{t} \boldsymbol{B}_{i}+e_{i t}
$$

where $R_{i}$ is a fund's monthly raw return, net of fees charged to investors, and the vector $\boldsymbol{X}$ contains factors that determine the fund's expected return. Equation (1) captures the abnormal return of hedge funds by taking into account eight hedge fund specific factors in the vector $\boldsymbol{X}$, seven factors from Fung and Hsieh (2004) and a liquidity risk exposure factor from Pástor and Stambaugh (2002). ${ }^{10}$ In equation (1), the term $a_{i}$ is the time invariant component of a fund's performance ("fund alpha") and $e$ is the residual. We estimate fund alphas and factor loadings on $\boldsymbol{X}$ by running fund-level longitudinal regressions and then compute the fund's information ratio by dividing the fund alpha by the standard deviation of the residual. ${ }^{11}$ We then compute firmlevel information ratios by averaging across all the funds in the same firm, weighting each fund's returns by its assets under management. ${ }^{12}$

\section{Parent firm location}

Our key independent variable measures the location of a hedge fund manager's previous employer. Specifically, we capture whether the headquarters of a manager's previous employer ("parent firm") was in one of the geographical hubs of the financial service industry-New York or London. ${ }^{13}$ We measure parent firm location as a binary variable, PARENT_CENTER, which equals 1 if the location of the previous employer is New York City or London and 0 otherwise. ${ }^{14}$

10 The Fung and Hsieh factors are available at http://faculty.fuqua.duke.edu/ dah7/HFData.htm. The PastorStambaugh liquidity factors are available at http://finance.wharton.upenn.edu/ stambaug/ liq_data_1962_2008.txt. The results are robust to using raw returns, and firm alphas.

${ }^{11}$ To control for outliers, we windsorize the information ratios at the $1^{\text {st }}$ and $99^{\text {th }}$ percentiles.

${ }^{12}$ For more detail on the approach, see also de Figueiredo and Rawley (2011).

${ }^{13}$ New York and London account for the world's largest equity, debt and derivatives markets and have been ranked as the top two global financial centers by the Global Financial Centers Index and the Worldwide Centers of Commerce Index in every year these indices were compiled. The results are robust to allowing New York and London location dummies to enter separately.

${ }^{14}$ In the absence of the exact location of a manager's job spells, headquarters location is a frequently used proxy (Klepper and Simons, 2000; Gompers, Lerner and Scharfstein, 2005). Measurement error in location leads to a bias toward zero as long as the classification error is uncorrelated with the regression disturbance term. In our case, the most plausible way in which this assumption would be violated would be if firms headquartered outside of New 
PARENT_CENTER is a coarse explanatory variable as it picks up the appropriable component of the sum of all three Marshallian (1920) sources of agglomeration effects that a nascent entrepreneur can transfer from a parent firm to a spawn. In other words, the coefficient estimate on PARENT_CENTER is an estimate of the product of: agglomeration effects at the parent firm level, appropriation of the benefits of agglomeration at the individual level within a parent firm and the transference of appropriated agglomeration effects from parent to spawn via an entrepreneurial manager.

In order to understand inherited agglomeration effects at a deeper level, we also characterize the relatedness of hedge fund managers' previous experience to see if inherited agglomeration effects increase with closely related work experience, as predicted by the theory. While almost all of the managers in our sample worked in finance in some capacity before starting or joining a hedge fund, interviews with industry experts suggest that investment management-investing in financial securities or active management of investments - is the type of job most closely related to hedge fund management. Thus, if our theory is correct, then we should see that managers with investment management experience are the most important transmitters of agglomeration effects between parent firms and hedge fund spawns.

To create an investment manager dummy variable, we coded as "1" any parent firm job spell in financial securities trading (third party or proprietary trading), mutual fund management, asset management, trust management, wealth management, private banking, pension fund management/institutional investor fund management, hedge fund/alternative investment management. Other job spells were coded as zero, including any other finance or non-finance related job, most notably corporate finance professionals, brokers, research analysts, commercial

York and London systematically assigned workers with the highest unobservable abilities (to the econometrician) to their New York or London offices. However, even if ability and location are correlated the bias will be toward zero because misclassified high ability workers will increase the measured performance of the control group. 
bankers, consultants, lawyers, accountants and academics. ${ }^{15}$ We interact the investment manager dummy variable with parent firm location to create a variable that measures the marginal effect of closely related experience on hedge fund performance.

Table 2 shows the summary statistics for the dependent, independent and control variables at the job spell level. The average information ratio is 0.27 , or 27 basis points per month per unit of risk with a standard deviation of 0.28. 58 percent of job spells were in New York or London, and 43 percent of job spells were in investment management. The t-test on spawn performance from managers who previously worked for incumbents in New York or London, compared to firms with managers that were not from New York or London, reveals that the former have higher information ratios by an average of 0.04 (the t-statistic on the difference is 1.94).

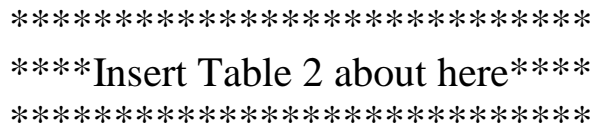

\section{Control variables}

We include three types of control variables in our analyses: manager controls, job spell controls and hedge fund controls. We use educational background measures to control for managers' ability before their employment spells with parent firms, including the median SAT score of each manager's undergraduate educational institution as well as a set of dummy variables for their highest educational level achieved. ${ }^{16}$ The data does not allow us to control for the component of a manager's ability that is uncorrelated with their educational background, which raises the possibility that unobservable ability may be correlated with both the manager's parent firm location and the subsequent performance of the manager's hedge fund. We discuss our

\footnotetext{
${ }^{15}$ Two research assistants coded job types independently of each other. Perreault and Leigh's (1989) reliability index was 0.89 , suggesting that the job type coding was very reliable.

${ }^{16}$ For the $37 \%$ of job spells missing in our data we include a missing SAT score dummy.
} 
approaches for dealing with endogeneity in more detail in the next sub-section.

Our proxies for parent firm quality include two direct measures of parent firm performance, whether the parent firm was ranked as a top 25 securities trading firm in any year 2000-2007 by Institutional Investor Magazine $(R A N K E D),{ }^{17}$ and the parent firm's average Tobin's Q. The Institutional Investor ranking is considered a good benchmark by industry experts for identifying high-quality trading firms. Since hedge funds are typically heavily engaged in securities trading, we include this measure to control for the quality of a manager's parent firm's trading capabilities. Tobin's Q provides a measure of how much market value a firm has created, which offers another measure of parent firm quality. We also include a control for the effects of industry relatedness, using a dummy variable based on whether the manager's job spell was in the financial industry, measured by the first digit of the parent firm's primary SIC code (SIC6).

Basic hedge fund controls include: scope, size, age and location. To control for traditional agglomeration effects, we introduce a binary variable, $H F_{-} C E N T E R$, which is set equal to one if the hedge fund is based in New York or London, and zero otherwise. We also include a binary variable, "hedge fund near center," set equal to one if the hedge fund is within 100 miles of New York City or London, and zero otherwise. Scope is measured as the log average number of funds in the hedge fund firm (equal weighted by month), size is measured as the monthly average firm-level aggregate assets under management (AUM) and age is measured as years since the firm was founded until exiting the sample or until the end of the sample period. 46 percent of jobs spells are related to hedge funds located in New York or London, and 14 percent

\footnotetext{
${ }^{17}$ There were thirteen securities trading rankings released by Institutional Investor during 2000-2007. These were Fixed Income Trading Ranking (2000, 2001); NYSE Equity Trading Ranking (2004, 2005); Nasdaq Equity Trading Ranking (2004, 2005); Derivatives Trading Ranking (2000, 2001, 2002, 2003, 2004); Alpha Securities Trading Ranking $(2006,2007)$. $74 \%$ of the job spells come from banks that were ranked in the top 25 , but only $25 \%$ of the parent firms in the sample were ranked in the top 25. The results are robust to allowing RANKED to enter as a count of the number of a times a firm was included in the top 25 trading firms in Institutional Investor.
} 
are associated with hedge funds that located near (but not in) New York City or London. The mean scope, size and age, by job spell, in our sample, are 4.1 funds, \$66M of AUM, and 7.35 years, respectively (Table 2).

\section{Empirical design}

In the ideal experiment we would randomly assign individuals to job spells at parent firms and then to senior management positions in hedge funds. In practice we must base our statistical tests on self-selected populations. Although we are concerned with endogeneity, the baseline tests of our first hypothesis are OLS regressions of hedge fund performance on parent firm location for hedge fund $i$ and job spell $j$ as in:

$$
\text { (2) IR }=a+\beta_{1} \text { PARENT_CENTER } R_{j}+\boldsymbol{X}_{c} \boldsymbol{\beta}_{c}+e_{i} \text {, }
$$

where $\boldsymbol{X}_{\boldsymbol{c}}$ is a vector of controls that might plausibly influence hedge fund performance, described above. Standard errors are clustered at the parent-firm level.

Because we rely on data generated by a non-experimental process to examine the relationship between parent firm location and spawn performance, the results are potentially affected by omitted variable bias (Nickerson and Hamilton, 2003). We are particularly concerned by two broad classes of endogeneity problems: selection into job spells by managers and selection into locations by firms. Job spell selection issues are employer-employee matching problems-firms choose employees and employees choose firms. There are also firm location selection decisions to consider: selection by parent firms into New York or London and hedge fund location decisions. Thus, we have four distinct selection issues to address: (i) ex ante job spell selection into parent firms, (ii) ex post job spell selection into hedge funds, (iii) parent firm location choice and (iv) hedge fund location choice. 


\section{Empirical strategy}

Because we do not observable individual or parent firm quality directly, and these characteristics might be correlated with the treatment (i.e., a parent firm job spell in New York/London) and the outcome of interest (i.e., performance), job spell selection issues are important to consider carefully in our context. For example, if the highest quality workers sort into NYC or Londonbased parent firms, then it is only natural that these workers' hedge funds outperform other hedge funds later. Even if there is no selection effect at the worker level if firms hired identical workers ex ante, but firms in New York or London produced higher levels of general human capital for their employees for reasons unrelated to agglomeration effects (e.g., due to better training) our results would be biased.

While job spell selection is potentially serious, our empirical strategy significantly mitigates the problem. First, we have data on managers' educational background and parent firm quality. Controlling for whether a bank was ranked in the top 25 trading firms by institutional investor is particularly important as it provides a useful measure of a parent firm's quality in the area most directly related to hedge funds. Second, we include parent-firm fixed effects for each of the bulge bracket investment banks: Citigroup, Credit Suisse, Goldman Sachs, JP Morgan, Lehman Brothers, Merrill Lynch and Morgan Stanley (Fang, 2005). If our results were influenced by firm quality, either through selecting better employees or through the provision of better training,

one should expect bulge bracket investment banks, like Goldman Sachs and Morgan Stanley, to drive the results. Third, to deal with selection effects that are correlated with the observable information about firms and workers, and to eliminate non-comparable treatment and control 
group observations, we use propensity score matching and Coarsened Exact Matching (CEM). ${ }^{18}$ Matching estimators control for selection bias by creating a matched sample of treatment and control observations that are similar with respect to the observable characteristics (Rosenbaum and Rubin, 1983). While matching cannot control for unobservable differences between workers and firms, it alleviates selection effects by reducing the observable differences between treatment and control groups. Thus, our analysis examines the effect of inherited agglomeration effects by comparing the performance of hedge fund managers with very similar educational and professional backgrounds. $^{19}$

Another potential source of selection bias would arise if managers in parent firms in New York and London have higher opportunity costs of leaving their parent firms such that only the best managers from these cities select into hedge fund founding or employment. More generally, if high-skill managers from parent firms in New York and London systematically joined hedge funds, then our estimates will be biased upward. However, the data shows that we probably have the opposite problem — a bias that works against finding a result. Because managers in New York and London have better opportunities to sort into hedge funds-deeper knowledge and better connections - and hedge funds tend to be extremely lucrative ventures, these managers are likely to possess lower levels of unobservable ability conditional on starting (or joining) a hedge fund. ${ }^{20}$ Moreover, we also address the issue by re-running our analyses, using the sub-sample of

\footnotetext{
${ }^{18}$ Coarsened Exact Matching (CEM) is similar to propensity score matching, but requires fewer post-estimation assumptions about how to define a match by matching observations exactly across a number of dimensions simultaneously (Iacus, King and Porro 2011.)

${ }^{19}$ Ideally, we would also use instrumental variables to deal with endogeneity concerns; however, the available instruments that satisfied the exclusion restriction were too weak in the first stage to be useful.

${ }^{20}$ Some evidence of lower quality selection bias from managers in New York or London can be seen in the raw data. The New York/London spawn rate in our sample is 177 per million employees (391 job spells spawned from a pool of 2.2 million employees). For firms outside New York/London in our sample the spawning rate is 85 per million employees (267 job spells spawned, from a pool of 3.1 million employees). Moreover, auxiliary analyses show that New York and London-based firms are $40 \%$ more likely to spawn new hedge funds and spawn almost 2.5 times as
} 
373 confirmed hedge fund founders (discussed in more detail below), and find very similar results. Since founders, by definition, start hedge funds, the analysis eliminates the parent firm component of ex post job spell selection.

Though parent firm location is also a choice variable, intuitively parent firm location selection problems would appear to be less severe for our study since most of the action in our analyses is at the job spell level. Parent firm location decisions were typically made in the distant past, for example Goldman Sachs was founded in New York in 1869, which suggests that the link between parent firm location choice and the effects we estimate are unlikely to be strong. However, it is still possible that there is a correlation between parent firm quality and location choice. Theoretically it is ambiguous whether agglomerated centers would attract or repel the strongest financial services firms (Shaver and Flyer 2000), but, in practice, New York and London appear to have attracted the best trading firms historically. Thus, we investigate how the results would be affected if better parent firms selected into New York or London by including controls for firm quality, controlling for selection on observables, and through the inclusion of bulge bracket dummies, which control directly for unobservable firm-specific quality for a crucial subset of parent firms. Finally, the endogeneity of hedge fund location decisions is relatively easy to deal with since we control for hedge fund location directly.

While detailed controls, firm fixed effects and matching address the most pressing endogeneity concerns, the cross-sectional structure of the data does not allow us to control directly for a manager's unobservable ability. If ability is uncorrelated with educational background and parent firm employer characteristics, but is correlated with the manager's decision to select into a job spell in New York or London, then our results will be biased upward.

many hedge funds compared to financial firms outside of New York and London, controlling for parent firm size and other parent firm characteristics (excluding non-financial firms). 
We must, therefore, interpret the results cautiously.

\section{RESULTS AND DISCUSSION}

\section{Matching estimators}

To implement propensity score matching, we estimate a probit of the individual and employer's joint decision to enter into an employment relationship in New York City or London and use fitted values from that model as estimates of the propensity score: $\operatorname{Pr}\left(\right.$ PARENT_CENTER $R_{i}=$ $\left.1 \mid \boldsymbol{X}_{i j}\right)$, where $\boldsymbol{X}_{i j}$ includes all the observable characteristics of individuals and their employer firms that might plausibly have an effect on either party's decision to enter into the employment relationship (i.e. all the individual and parent firm covariates from the OLS specification (2)). We then trim extreme values and observations off the common support of the propensity score distribution to obtain our matched sample. ${ }^{21}$

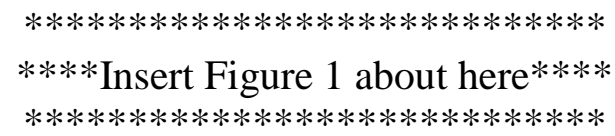

Figure 1 reveals why matching matters. In Figure 1A the distributions of the propensity scores before matching are quite different between the treatment and control groups. Figure 1B shows the distributions of the propensity scores after matching. Visually there is a much tighter fit between the two groups after matching. We also corroborate this result statistically. Before matching a number of covariates are statistically different between the control and treatment groups, and the F-test for the joint difference in means between the two groups before matching is statistically significant at the one percent level. After matching the differences between the control and treatment groups decrease substantially. Only the difference in the means on RANKED remains significant at the five percent level, and the F-test for the joint significance of

\footnotetext{
${ }^{21}$ We trim observations at the $10^{\text {th }}$ and $98^{\text {th }}$ percentiles of the distribution of the probability of the job spell occurring in New York, though other reasonable cut points generated similar second stage results. CEM eliminates the subjective decision about the points at which to trim off extreme values.
} 
the differences in means between the treatment and control groups is not significant at the 10 percent level (p-value of 0.39). In other words, the matching approach creates treatment and control group job spells that are similar along observable dimensions ex ante.

To implement Coarsened Exact Matching (CEM), continuous variables are "coarsened" or converted into splines for the purposes of creating "bins", or discrete mutually exclusive bundles of control variables. Treatment and control observations are then matched exactly within each bin, which eliminates the need to compare the means of the treatment and control groups after matching. To avoid making ad hoc assumptions about how to partition variables, we allow the CEM algorithm to automatically coarsen the continuous variables in our regressions. We also allow for unbalanced matching within each bin, as recommended by Iacus, King and Porro (2011). As a result, we adjust the second stage regressions (below) by the CEM sample weights so that the results can be interpreted as average treatment effects; however, the results are robust to forcing the matches to be one-to-one.

\section{Inherited agglomeration effects}

Figure 2 illustrates our main results graphically by splitting out hedge fund performance into deciles by three types of managers, managers from agglomerated parents ("CENTER"), managers from non-agglomerated parents ("non-CENTER") and the sub-sample of managers who were both employed by an agglomerated parent and worked in investment management (“Inv. Mgmt. CENTER”), after matching. In all ten deciles, the managers from agglomerated parent firms outperform mangers from non-agglomerated parent firms, with the differences being significant at the 5 percent level in eight of the deciles. Moreover, in nine deciles managers from agglomerated parent firms who also worked in investment management outperformed other managers who worked for agglomerated parent firms, and the difference is significant at the five 
percent level in eight of the deciles.

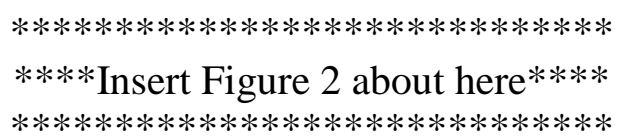

Table 3 shows our main result; regressions of hedge fund spawn performance (i.e., the information ratio) on parent firm location. In column 1, the coefficient estimate on parent firm location (PARENT_CENTER) without controls is four basis points per month per unit of risk, and is statistically significant at the $10 \%$ level. Including the full set of controls except the seven bulge bracket fixed effects, in column 2, has little effect on the coefficient on parent firm location. After including seven bulge bracket firm fixed effects to control for unobservable parent-firm effects amongst the largest and most important financial institutions, the coefficient on parent firm location increases to 10 basis points per month, while the coefficient on hedge fund location (HF_CENTER) is 4 basis points per month, and both are precisely estimated (column 3). After propensity score matching, the coefficient on parent firm location is 14 basis points per month per unit of risk (column 4) and is significant at the one percent level, which at the average level of risk taking in our sample translates to 1.1 percent per year of excess return. ${ }^{22}$ The CEM results are nearly identical (column 5). Comparing the matched sample results to the OLS results, selection bias appears to work against finding a result in our baseline tests by biasing the coefficient estimates toward zero. Taken together, the results suggest that inherited agglomeration effects are positive, economically and statistically significant, and at least as large as conventional agglomeration effects. ${ }^{23}$

\footnotetext{
${ }^{22}$ Average annual excess returns can be recovered by multiplying the information ratio by the standard deviation of alpha (i.e., "the average level of risk taking in our sample") and multiplying by twelve: 0.14 x 0.64 x $12=1.1 \%$.

${ }^{23}$ Partitioning inherited agglomeration effects into New York and London-specific effects yields precisely estimated point estimates of 0.08 to 0.10 for New York, and 0.15 to 0.23 for London. However, New York and London effects are not statistically different from one another in any of the specifications.
} 
$* * * * * * * * * * * * * * * * * * * * * * * * * * * *$

$* * * *$ Insert Table 3 about here****

$* * * * * * * * * * * * * * * * * * * * * * * * * * * *$

In Table 4, we test whether inherited agglomeration effects are larger for managers with closely related experience (i.e., managers with investment management experience) by interacting parent firm location with an investment management dummy. In column 1, the marginal effect of investment management experience on performance, conditional on inherited agglomeration effects is eight basis points per month per unit of risk, but is only significant at the ten percent level. However, we know from Table 3 that selection effects bias our results toward zero. Columns (2) and (3) show that the marginal effect of investment management experience on performance is 11 basis points per month per unit of risk after correcting for selection bias and statistically significant at the $5 \%$ and $10 \%$ level using propensity score matching and CEM, respectively.

$* * * * * * * * * * * * * * * * * * * * * * * * * * * *$
$* * * *$ Insert Table 4 about here****
$* * * * * * * * * * * * * * * * * * * * * * * * * * * *$

To probe inherited agglomeration effects further, we conduct two additional analyses: (i) an analysis to ascertain whether knowledge transfers or social capital transfers, or both, appear to be driving the transference of agglomeration effects in the context of hedge funds and (ii) a subsample analysis on the set of hedge fund managers who are confirmed founders.

While our data does not allow us to measure the transference of knowledge or social capital directly, we exploit a distinction in the investment strategies of hedge funds to tease apart these two mechanisms. For hedge funds that directly invest in financial securities, both knowledge of investment strategies and social capital are important for firm performance. However, for fundof-funds, which only invest in other hedge funds, knowledge of investment strategies, 
particularly the implementation of such strategies, is somewhat less important. At the same, time, social capital continues to play a crucial role in building relationships with direct investment funds and investors (Rider 2009). Therefore, if we find evidence for inherited agglomeration effects for direct investment funds but not for fund-of-funds, it would suggest that inherited agglomeration effects are mainly driven by trading knowledge spilling over, whereas if we find both direct investment funds and fund-of-funds experience inherited agglomeration effects that would suggest that social capital accumulation is the key mechanism behind inherited agglomeration effects.

In Table 5, columns 1a and 1b, we split the sample into direct investment funds and fund-offunds, respectively, and rerun our regressions on these subsamples. We find that for direct investment funds the coefficient on parent firm location is positive and statistically significant; however, for fund-of-funds the coefficient on parent firm location is indistinguishable from zero. While the difference between the coefficient estimates on parent firm location are not statistically different in the two samples, the results suggest that spillovers of technical knowledge are the key mechanism underlying inherited agglomeration effects in hedge funds.

\footnotetext{
$* * * * * * * * * * * * * * * * * * * * * * * * * * * *$

$* * * *$ Insert Table 5 about here $* * * *$

$* * * * * * * * * * * * * * * * * * * * * * * * * * * *$
}

While not all the managers in our dataset are founders, all are senior executives who have a significant influence on the performance of the hedge fund. Still, it would be interesting to know whether our results are robust to tests on the founder-only sample, particularly because much of the spawning literature focuses on founders. To obtain this sample, we code whether the principal manager of a hedge fund firm was a founder of the hedge fund or a non-founding principal based on biographical descriptions in the MARHedge data, internet searches and an alternative hedge fund manager database (i.e., Morningstar). 373 jobs spells, in our sample, 
could be definitively associated with managers who were hedge fund founders. ${ }^{24}$ The remaining 285 observations were associated with non-founders, or with individuals whose founding status was indeterminate. The results from the founder sub-sample analysis, shown in Table 5, column (2), are almost identical to the full-sample results.

\section{CONCLUSION}

This paper develops the concept of inherited agglomeration effects: human capital that managers acquire while working in an industry hub that may be transferred to a spinoff. We test the predictions of the theory in the context of the global hedge fund industry. The results show that hedge funds whose principal managers were previously employed by parent firms located in financial services industry hubs-New York or London-outperform other hedge funds by approximately one per cent per year, an effect size that is at least as large as traditional agglomeration effects.

The evidence is consistent with the idea that managers develop greater generalized human capital when working for parent firms in industry hubs, which they can transmit to new ventures. Although we cannot completely rule out selection on unobservables, the results suggest that inherited agglomeration effects have a meaningful impact on new venture performance. The paper also extends the agglomeration literature on entrepreneurship, which has largely focused on the benefits of agglomeration internal to the industry hub, by explicating how the benefits of agglomeration diffuse outside industry hubs into peripheral regions. Finally, this paper contributes to the micro-foundations of the strategy literature on how firm performance is shaped by the human capital of its key managers.

Scholars interested in further studying inherited agglomeration effects would be well served

\footnotetext{
${ }^{24}$ Two research assistants coded whether the principal manager was involved in the founding of the hedge fund. Perreault and Leigh's reliability index (1989) was 0.77, suggesting that the coding was reliable.
} 
to explore settings where manager ability could be controlled for directly by developing manager-specific performance metrics before and after the spawning event. Using a panel data research design with manager fixed effects would address the main shortcoming of this research by dealing with potential selection based on ability in a parsimonious manner. For example, in our setting the strength of the causal inference would be improved if we had a reliable measure of the manager's performance before they joined a hedge fund. It is possible that such ex ante performance measures could be developed by focusing on a subset of hedge fund managers who worked in positions where performance is attributable to the manager, easily measurable and comparable across managers. We believe portfolio managers in mutual funds, or investment analysts, who subsequently entered the hedge fund industry, are particularly interesting subpopulations within which to explore inherited agglomeration effects in more detail. 


\section{References}

Agarwal R, Echambadi R, Franco AM, Sarkar MB. 2004. Knowledge transfer through inheritance: Spinout generation, development, and survival. Academy of Management Journal 47(4): 501-522.

Agarwal R, Audretsch D, Sarkar MB. 2007. The process of creative construction: Knowledge spillovers, entrepreneurship, and economic growth. Strategic Entrepreneurship Journal 1(3/4): 263286.

Aldrich H. 1999. Organizations Evolving. SAGE Publications: London; Thousand Oaks, CA.

Audretsch DB, Feldman MP. 1996. R\&D spillovers and the geography of innovation and production. American Economic Review 86(3): 630-640.

Bell GG, Zaheer A. 2007. Geography, networks, and knowledge flow. Organization Science 18(6): 955972.

Berchicci, L, King, A, Tucci, CL. 2011. Does the apple always fall close to the tree? The geographical proximity choice of spin-outs. Strategic Entrepreneurship Journal 5(2): 120-136.

Bhide A. 2000. The Origin and Evolution of New Businesses. Oxford University Press: Oxford, England.

Boeker WP. 1988. Organizational origins: Entrepreneurial and environmental imprinting at the time of founding. In Ecological Models of Organizations, Carroll G, Hawley AH (eds). Ballinger: Cambridge, MA; 33-52.

Braun E, Macdonald S. 1982. Revolution in Miniature: The History and Impact of Semiconductor Electronics Re-explored. Cambridge University Press: Cambridge, England.

Burton MD, Sorensen JB, Beckman CM. 2002. Coming from good stock: Career histories and new venture formation. In Research in the Sociology of Organization, Lounsbury M. and Ventresca MJ (eds). Elsevier: Oxford, England; 229-262.

Cardinal LB, Sitkin SB, Long CP. 2004. Balancing and rebalancing in the creation and evolution of organizational control. Organization Science 15(4): 411-431.

Chatterji, AK. 2009. Spawned with a silver spoon? Entrepreneurial performance and innovation in the medical device industry. Strategic Management Journal 30(2): 185-206.

Dahl MS, Klepper S. 2008. Whom do new firms hire? Carnegie Mellon working paper.

de Figueiredo RJP Jr., Rawley E. 2011. Skill, luck and the multi-product firm: Evidence from hedge funds. Management Science 57(11): 1953-1968.

Dencker CD, Gruber M, Shah SK. 2009. Pre-entry knowledge, learning, and the survival of new firms. Organization Science 20(3): 516-537.

Eisenhardt KM, Schoonhoven CB. 1990. Organizational growth: linking founding team, strategy, environment, and growth among U.S. semiconductor ventures, 1978-1988. Administrative Science Quarterly 35(3): 504-529.

Elfenbein DW, Hamilton BH, Zenger TR. 2010. The small firm effect and the entrepreneurial spawning of scientists and engineers. Management Science 56(4): 659-681.

Ellison G, Glaeser EL, Kerr WR. 2010. What causes industry agglomeration? Evidence from coagglomeration patterns. American Economic Review 100(3): 1195-1213.

Fang, LH. 2005. Investment bank reputation and the price and quality of underwriting services. Journal of Finance 60(6): 2729-2761.

Fern MJ, Cardinal LB, O'Neill HM. 2011. The genesis of strategy in new ventures: Escaping the constraints of founder and team knowledge. Strategic Management Journal (forthcoming).

Florin J, Lubatkin M, Schulze W. 2003. A social capital model of high-growth ventures. Academy of Management Journal 46(3): 374-384.

Franco AM, Filson D. 2006. Spin-outs: Knowledge diffusion through employee mobility. RAND Journal of Economics 37(4): 841.

Fung W, Hsieh DA. 2004. Hedge fund benchmarks: A risk based approach. Financial Analysts Journal 60(5): $65-80$.

Glaeser EL, Kallal HD, Scheinkman JA, Shleifer A. 1992. Growth in cities. The Journal of Political Economy 100(6): 1126-1152.

Gompers P, Lerner J, Scharfstein D. 2005. Entrepreneurial spawning: Public corporations and the genesis 
of new ventures, 1986 to 1999. The Journal of Finance 60(2): 577-614.

Groysberg B, Lee L, Nanda A. 2008. Can they take it with them? The portability of star knowledge workers' performance. Management Science 54(7): 1213-1230.

Gruber M, MacMillan IC, Thompson JD. 2008. Look before you leap: Market opportunity identification in emerging technology firms. Management Science 54(9): 1652-1665.

Gulati R, Higgins MC. 2003. Which ties matter when? The contingent effects of interorganizational partnerships on IPO success. Strategic Management Journal 24(2): 127-144.

Hedge Fund Research, 2010. Global Hedge Fund Industry Report, First Quarter.

Helfat CE, Lieberman MB. 2002. The birth of capabilities: Market entry and the importance of prehistory. Industrial and Corporate Change 11(4): 725-760.

Hellmann T. 2007. When do employees become entrepreneurs? Management Science 53(6): 919-933.

Helsley RW, Strange WC. 1990. Matching and agglomeration economies in a system of cities. Regional Science and Urban Economics 20(2): 189-212.

Iacus SM, King G, Porro G. 2011. Causal inference without balance checking: Coarsened exact matching. Political Analysis (forthcoming).

Jaffe AB, Trajtenberg M, Henderson R. 1993. Geographic localization of knowledge spillovers as evidenced by patent citation. Quarterly Journal of Economics 108(3):577-598.

Johnson, V. 2007. What is organizational imprinting? Cultural entrepreneurship in the founding of the Paris Opera. American Journal of Sociology 113(1): 97-127.

Klepper S. 2007. The geography of organizational knowledge. Carnegie Mellon Working Paper.

Klepper S, and Simons KL. 2000. Dominance by birthright: Entry of prior radio producers and competitive ramifications in the U.S. television receiver industry. Strategic Management Journal 21(10-11): 997-1016.

Klepper S, Sleeper S. 2005. Entry by spin-offs. Management Science 51(8): 1291-1306.

Marshall A. 1920. Principles of Economics. Macmillan: London, England

Nickerson JH, Hamilton BH. 2003. Correcting for endogeneity in strategic management research, Strategic Organization 1(1): 53-80.

Pástor L, Stambaugh RF. 2002. Mutual fund performance and seemingly unrelated assets. Journal of Financial Economics 63(3): 315-349.

Perreault WD, Leigh LE. 1989. Reliability of nominal data based on qualitative judgments. Journal of Marketing Research 26(2): 135-48.

Phillips D. 2002. A genealogical approach to organizational life chances: The parent-progeny transfer among Silicon Valley law firms, 1946-1996. Administrative Science Quarterly 47(3): 474-506.

Rider C. 2009. Constraints on the control benefits of brokerage: A study of placement agents in U.S. venture capital fundraising. Administrative Science Quarterly 54(4): 575-601.

Rosenbaum PR, Rubin DB. 1983, The central role of the propensity score in observational studies for causal effects. Biometrika 70(1): 41-55.

Saxenian A. 1994a. Regional Advantage: Culture and Competition in Silicon Valley and Route 128. Harvard University Press: Cambridge, MA.

Saxenian A. 1994b. Lessons from Silicon Valley. Technology Review 97(5): 42-51.

Shaver MJ, Flyer F. 2000. Agglomeration economies, firm heterogeneity and foreign direct investment in the United States. Strategic Management Journal, 21(12): 1175-1193.

Stinchcombe AL. 1965. Social structure and organizations. In Handbook of Organizations, March, J. (ed). Rand McNally: Chicago, IL.

Stuart T, Sorenson O. 2003. The geography of opportunity: Spatial heterogeneity in founding rates and the performance of biotechnology firms. Research Policy 32(2): 229-253.

Toole AA, Czarnitzki D. 2009. Exploring the relationship between scientist human capital and firm performance: The case of biomedical academic entrepreneurs in the SBIR program. Management Science 55(1): 101-114. 


\section{Figure 1}

Kernel density distributions of the probability of a job spell occurring in New York or London

Figure 1A: Kernel density distributions of the probability of a job spell occurring in New York or London before matching $(n=658)$

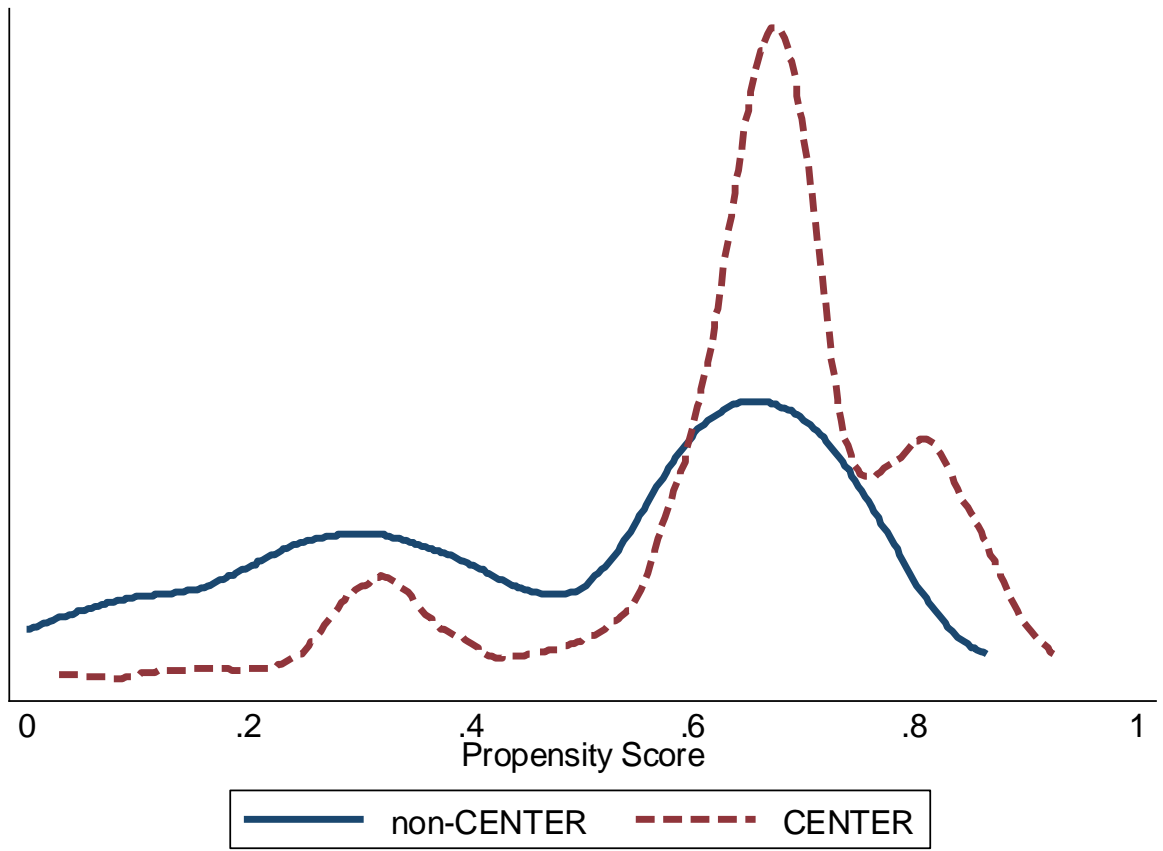

Figure 1B: Kernel density distributions of the probability of a job spell occurring in New York or London after matching $(n=466)$

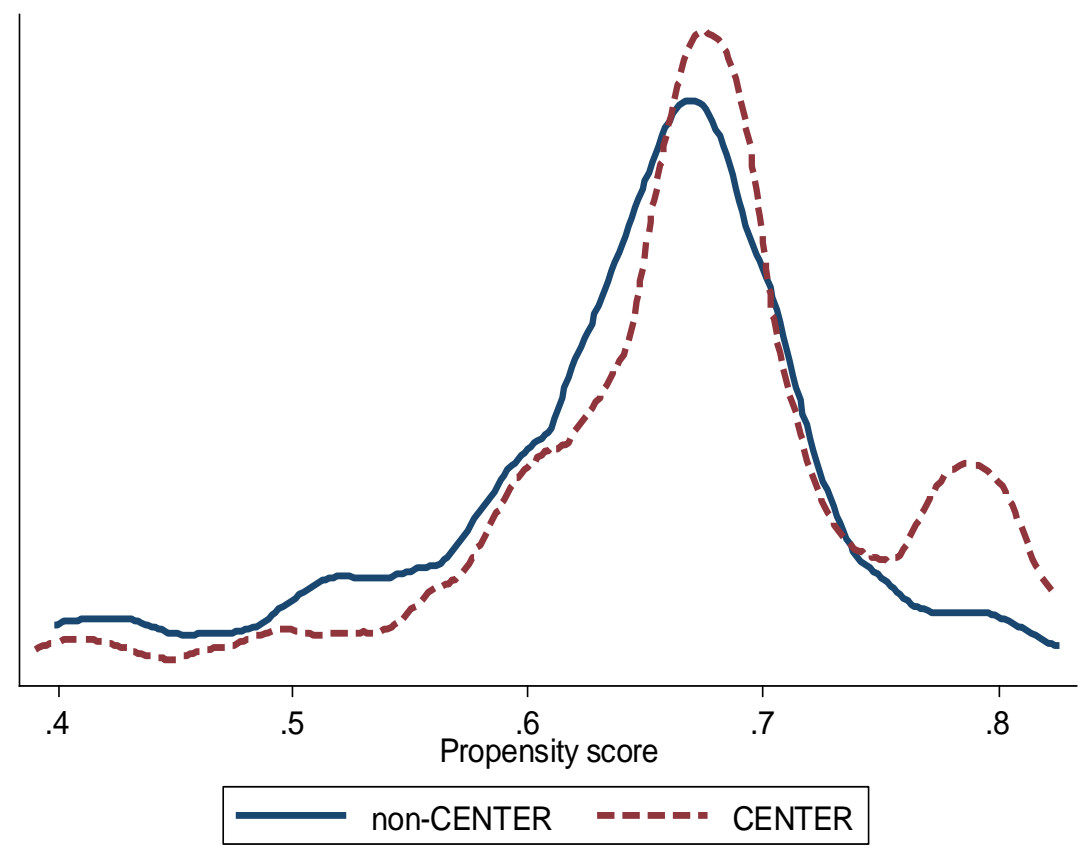


Figure 2

8-factor information ratio by decile

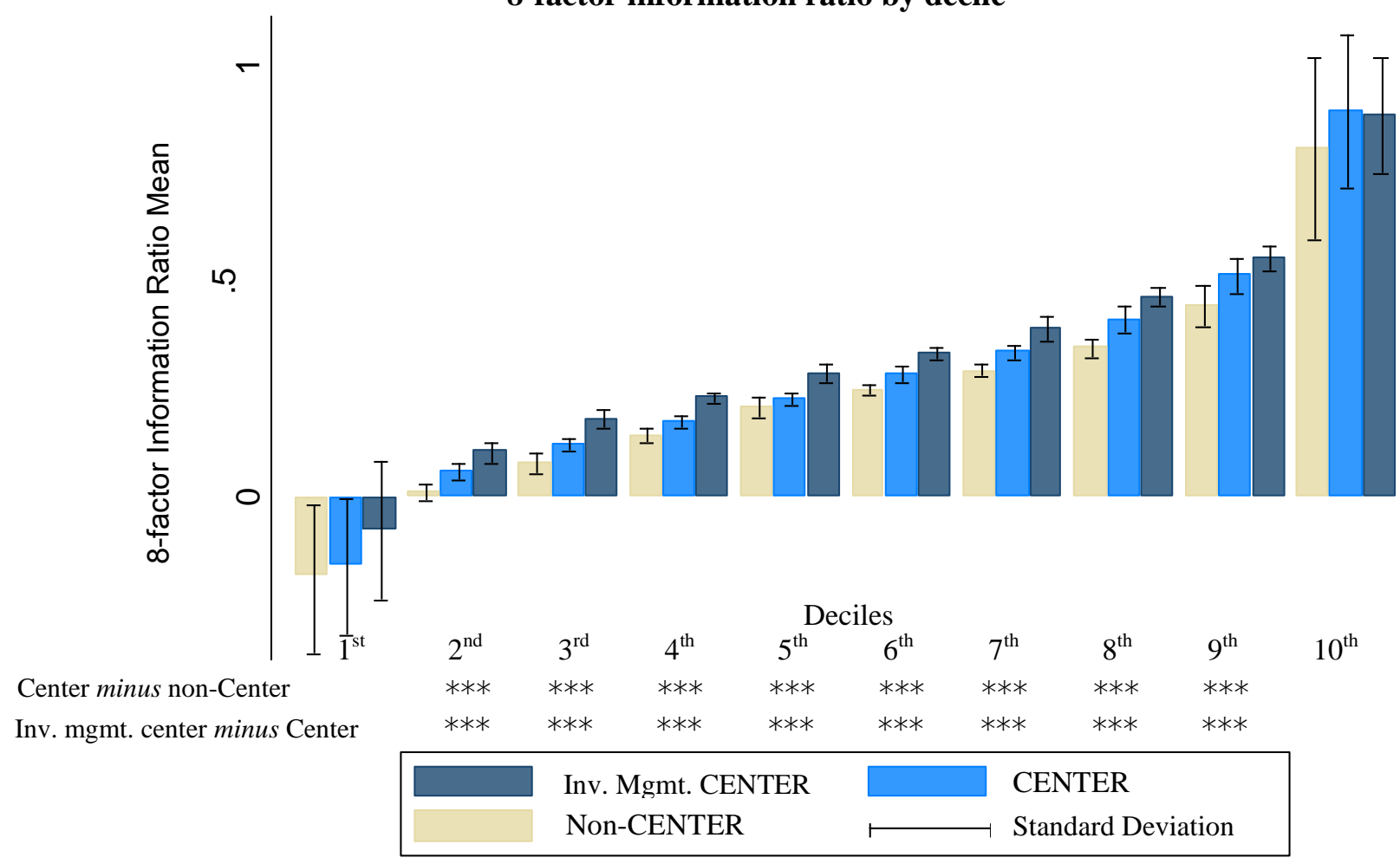

Propensity score matched sample results $(n=466)$.

Statistical difference in 8 - factor information ratio means:

$*$ significant at the $10 \%$ level; ** significant at the 5\% level; *** significant at the $1 \%$ level 
Table 1

Top 25 parent firms by number of job spells spawned

\begin{tabular}{|c|c|c|c|c|c|c|}
\hline Firm & HQ Location & $\begin{array}{c}\text { Bulge } \\
\text { bracket }\end{array}$ & Ranked & $\begin{array}{l}\text { SIC } \\
\text { code }\end{array}$ & $\begin{array}{l}\text { Emps. } \\
\left({ }^{\circ} 000\right)\end{array}$ & $\begin{array}{r}\text { \# of job } \\
\text { spells } \\
\text { spawned }\end{array}$ \\
\hline Citigroup & New York & Y & $\mathrm{Y}$ & 61 & 387 & 68 \\
\hline JP Morgan & New York & Y & $\mathrm{Y}$ & 60 & 181 & 54 \\
\hline Merrill Lynch & New York & $\mathrm{Y}$ & Y & 62 & 64 & 50 \\
\hline Deutsche Bank & Frankfurt & $\mathrm{N}$ & Y & 60 & 78 & 42 \\
\hline Lehman Brothers & New York & Y & $\mathrm{Y}$ & 62 & 29 & 38 \\
\hline Morgan Stanley & New York & Y & $\mathrm{Y}$ & 62 & 48 & 32 \\
\hline Goldman Sachs & New York & $\mathrm{Y}$ & Y & 62 & 31 & 31 \\
\hline UBS & Zurich & $\mathrm{N}$ & Y & 62 & 84 & 29 \\
\hline Bear Stearns & New York & $\mathrm{N}$ & $\mathrm{Y}$ & 62 & 14 & 25 \\
\hline Bank of America & Charlotte & $\mathrm{N}$ & $\mathrm{Y}$ & 60 & 210 & 21 \\
\hline Credit Suisse & Zurich & Y & Y & 62 & 48 & 18 \\
\hline RBS & Edinburgh & $\mathrm{N}$ & $\mathrm{Y}$ & 60 & 200 & 17 \\
\hline Oppenheimer & Toronto & $\mathrm{N}$ & $\mathrm{N}$ & 62 & 3 & 12 \\
\hline ING & Amsterdam & $\mathrm{N}$ & $\mathrm{N}$ & 63 & 120 & 12 \\
\hline Bankers Trust & New York & $\mathrm{N}$ & $\mathrm{N}$ & 60 & 21 & 10 \\
\hline Wells Fargo & San Francisco & $\mathrm{N}$ & $\mathrm{Y}$ & 60 & 160 & 10 \\
\hline Schroders & London & $\mathrm{N}$ & $\mathrm{N}$ & 62 & 3 & 10 \\
\hline Barclays & London & $\mathrm{N}$ & $\mathrm{Y}$ & 60 & 156 & 10 \\
\hline Allianz & Munich & $\mathrm{N}$ & $\mathrm{N}$ & 63 & 181 & 9 \\
\hline Invesco & Atlanta & $\mathrm{N}$ & $\mathrm{N}$ & 62 & 7 & 8 \\
\hline $\mathrm{RBC}$ & Montreal/Toronto & $\mathrm{N}$ & $\mathrm{Y}$ & 60 & 65 & 6 \\
\hline Alliance Bernstein & New York & $\mathrm{N}$ & Y & 67 & 6 & 6 \\
\hline Prudential Financial & Newark & $\mathrm{N}$ & $\mathrm{Y}$ & 63 & 41 & 6 \\
\hline CIB & Toronto & $\mathrm{N}$ & $\mathrm{Y}$ & 60 & 41 & 6 \\
\hline HSBC & London & $\mathrm{N}$ & $\mathrm{Y}$ & 60 & 313 & 5 \\
\hline
\end{tabular}

Other firms that had more than one job spell associated with a hedge fund spawn include: AIG (New York), Alex Brown \& Sons (Baltimore), American Express (New York), Allegheny Energy (Greensburg), BlackRock (New York), Bank of New York Mellon (New York), Bank of Montreal (Montreal), Chevron (San Ramon), Cowen and Co. (New York), Diamond Hill Investment Group (Columbus), Digex (New York), Franklin Templeton (San Mateo), Gabelli and Co. (Rye), Gartner Group (Stamford), General Electric (Fairfield), Hill Samuel (London), IBM (Armonk), Ladenburg, Thalman and Co. (Miami), Lazard (New York), Morgan Keegan (Birmingham), NASDAQ (New York), Nomura (Tokyo), Northern Trust Global Investments (Chicago), Principal Financial Group (Des Moines) Standard Chartered (London), State Street Advisors (Boston), T. Rowe Price (Baltimore), Value line (New York). 
Table 2

Summary statistics

\begin{tabular}{|c|c|c|c|c|c|c|c|}
\hline $\mathrm{n}=658$ & mean & SD & median & $\min$ & $\max$ & $\begin{array}{r}\text { mean } \\
\left(P A R E N T_{-}\right. \\
C E N T E R=0) \\
\mathrm{n}=278\end{array}$ & $\begin{array}{r}\text { mean } \\
\left(P A R E N T_{-}\right. \\
C E N T E R=1) \\
\mathrm{n}=380\end{array}$ \\
\hline \multicolumn{8}{|l|}{$\underline{\text { Hedge fund firm level variables }}$} \\
\hline 8 -factor information ratio ${ }^{a}$ & 0.27 & 0.28 & 0.24 & -0.58 & 1.18 & 0.25 & 0.29 \\
\hline HF_CENTER & 0.46 & 0.50 & 0 & 0 & 1 & 0.42 & 0.48 \\
\hline $\begin{array}{l}\text { Hedge fund located near } \\
\text { financial center }\end{array}$ & 0.14 & 0.35 & 0 & 0 & 1 & 0.16 & 0.13 \\
\hline Hedge fund age (years) & 7.35 & 4.24 & 6.0 & 2 & 24 & 6.40 & 8.05 \\
\hline Avg. number of hedge funds & 4.14 & 5.19 & 2.56 & 1.0 & 53.3 & 3.74 & 4.53 \\
\hline Lifetime average AUM (in \$m) & 66.1 & 135.1 & 17.2 & 0.5 & 13,500 & 49.9 & 78.0 \\
\hline \multicolumn{8}{|l|}{ Parent firm level variables } \\
\hline PARENT_CENTER & 0.58 & 0.50 & 1 & 0 & 1 & 0 & 1 \\
\hline SIC6 & 0.94 & 0.23 & 1 & 0 & 1 & 0.89 & 0.98 \\
\hline Tobin's Q & 1.21 & 0.59 & 1.05 & 0.88 & 8.11 & 1.29 & 1.14 \\
\hline $\begin{array}{l}\text { RANKED in the top } 25 \text { by Inst. } \\
\text { Investor ' } 00-07\end{array}$ & 0.74 & 0.44 & 1 & 0 & 1 & 0.56 & 0.86 \\
\hline \multicolumn{8}{|l|}{ Individual manager level variables } \\
\hline Previous Job in Invest. Mgmt. & 0.43 & 0.50 & 0 & 0 & 1 & 0.44 & 0.43 \\
\hline MBA degree dummy & 0.36 & 0.48 & 0 & 0 & 1 & 0.38 & 0.35 \\
\hline $\mathrm{PhD}$ degree dummy & 0.04 & 0.20 & 0 & 0 & 1 & 0.04 & 0.04 \\
\hline JD degree dummy & 0.02 & 0.15 & 0 & 0 & 1 & 0.03 & 0.02 \\
\hline $\begin{array}{l}\text { Other postgraduate degree } \\
\text { dummy }\end{array}$ & 0.11 & 0.31 & 0 & 0 & 1 & 0.07 & 0.13 \\
\hline $\begin{array}{l}\text { Median SAT score of highest } \\
\text { education institution attended } \\
\text { Interaction variables }\end{array}$ & 1335 & 124 & 1362 & 834 & 1495 & 1327 & 1341 \\
\hline $\begin{array}{l}\text { Previous Job in Invest. Mgmt. } x \\
\text { PARENT_CENTER }\end{array}$ & 0.24 & 0.43 & 0 & 0 & 1 & 0 & 0.43 \\
\hline $\begin{array}{l}\text { Previous Job in Invest. Mgmt. } x \\
\text { HF_CENTER }\end{array}$ & 0.20 & 0.40 & 0 & 0 & 1 & 0.19 & 0.21 \\
\hline
\end{tabular}

${ }^{\mathrm{a}}$ The difference in the means for PARENT_CENTER=0 and PARENT_CENTER $=1$ is 4.34 basis points per month (bps/month) and the t-statistic on the difference in the means is 1.94 . 
Table 3

Inherited agglomeration effects

\begin{tabular}{|c|c|c|c|c|c|c|c|c|c|c|}
\hline Dependent variable: information ratio & $\begin{array}{r}(1) \\
\text { OLS }\end{array}$ & & $\begin{array}{r}(2) \\
\text { OLS }\end{array}$ & & $\begin{array}{r}(3) \\
\text { OLS }\end{array}$ & & $\begin{array}{r}(4) \\
\text { P-score }\end{array}$ & & $\begin{array}{r}(5) \\
\text { CEM }\end{array}$ & \\
\hline Parent firm in NYC or London (PARENT_CENTER) & $\begin{array}{r}0.04 \\
(0.03)\end{array}$ & $*$ & $\begin{array}{r}0.06 \\
(0.03)\end{array}$ & $* *$ & $\begin{array}{r}0.10 \\
(0.03)\end{array}$ & $* * *$ & $\begin{array}{r}0.14 \\
(0.05)\end{array}$ & $* * *$ & $\begin{array}{r}0.14 \\
(0.06)\end{array}$ & $* *$ \\
\hline Hedge fund in NYC or London (HF_CENTER) & & & $\begin{array}{r}0.05 \\
(0.02)\end{array}$ & $* *$ & $\begin{array}{r}0.04 \\
(0.02)\end{array}$ & $* *$ & $\begin{array}{r}0.06 \\
(0.03)\end{array}$ & $* *$ & $\begin{array}{r}0.06 \\
(0.03)\end{array}$ & $* *$ \\
\hline Parent firm SIC code begins with "6” (SIC6) & & & $\begin{array}{r}-0.04 \\
(0.05)\end{array}$ & & $\begin{array}{r}-0.05 \\
(0.05)\end{array}$ & & $\begin{array}{r}-0.13 \\
(0.08)\end{array}$ & & $\begin{array}{r}0.02 \\
(0.08)\end{array}$ & \\
\hline $\begin{array}{l}\text { Parent firm ranked as a top } 25 \text { trading firm by } \\
\text { Institutional Investor (RANKED) }\end{array}$ & & & $\begin{array}{r}0.00 \\
(0.03)\end{array}$ & & $\begin{array}{r}0.03 \\
(0.03)\end{array}$ & & $\begin{array}{r}0.06 \\
(0.06)\end{array}$ & & $\begin{array}{r}0.06 \\
(0.06)\end{array}$ & \\
\hline Parent firm's Tobin's Q & & & $\begin{array}{r}0.00 \\
(0.02)\end{array}$ & & $\begin{array}{r}0.00 \\
(0.02)\end{array}$ & & $\begin{array}{r}0.02 \\
(0.03)\end{array}$ & & $\begin{array}{r}-0.56 \\
(0.37)\end{array}$ & \\
\hline Hedge fund within 100 miles of NYC or London & & & $\begin{array}{r}0.01 \\
(0.02)\end{array}$ & & $\begin{array}{r}-0.00 \\
(0.04)\end{array}$ & & $\begin{array}{r}0.00 \\
(0.05)\end{array}$ & & $\begin{array}{r}-0.02 \\
(0.07)\end{array}$ & \\
\hline Hedge fund firm age & & & $\begin{array}{r}-0.01 \\
(0.00)\end{array}$ & $* * *$ & $\begin{array}{r}-0.01 \\
(0.00)\end{array}$ & $* * *$ & $\begin{array}{r}-0.02 \\
(0.00)\end{array}$ & $* * *$ & $\begin{array}{r}-0.01 \\
(0.00)\end{array}$ & $* * *$ \\
\hline $\begin{array}{l}\text { Log average number of funds in hedge fund firm } \\
\text { (scope) }\end{array}$ & & & $\begin{array}{r}-0.00 \\
(0.02)\end{array}$ & & $\begin{array}{r}0.00 \\
(0.02)\end{array}$ & & $\begin{array}{r}0.02 \\
(0.02)\end{array}$ & & $\begin{array}{r}-0.00 \\
(0.02)\end{array}$ & \\
\hline Log lifetime avg. AUM of hedge fund firm (size) & & & $\begin{array}{r}0.01 \\
(0.01)\end{array}$ & & $\begin{array}{r}0.01 \\
(0.01)\end{array}$ & & $\begin{array}{r}0.00 \\
(0.01)\end{array}$ & & $\begin{array}{r}0.01 \\
(0.01)\end{array}$ & \\
\hline Manager's previous job in investment management & & & $\begin{array}{r}-0.02 \\
(0.03)\end{array}$ & & $\begin{array}{r}-0.01 \\
(0.03)\end{array}$ & & $\begin{array}{r}0.03 \\
(0.03)\end{array}$ & & $\begin{array}{r}0.00 \\
(0.03)\end{array}$ & \\
\hline Constant & $\mathrm{Y}$ & $* * *$ & Y & & Y & & Y & & Y & \\
\hline Missing data dummies & $\mathrm{N}$ & & Y & & Y & & Y & & $\mathrm{Y}$ & \\
\hline Manager's SAT score quintile dummies & $\mathrm{N}$ & & Y & & Y & & $\mathrm{Y}$ & & Y & \\
\hline Manager's graduate degree dummies & $\mathrm{N}$ & & Y & & Y & & Y & & $\mathrm{Y}$ & \\
\hline 7 parent firm bulge bracket dummies & $\mathrm{N}$ & & $\mathrm{N}$ & & $\mathrm{Y}$ & & $\mathrm{Y}$ & & Y & \\
\hline $\mathrm{N}$ & 658 & & 658 & & 658 & & 466 & & 423 & \\
\hline $\mathrm{R}^{2}$ & 0.01 & & 0.09 & & 0.11 & & 0.14 & & 0.14 & \\
\hline
\end{tabular}

* significant at the $10 \%$ level; ** significant at the 5\% level; *** significant at the $1 \%$ level

Standard errors (in parentheses) are robust and clustered at the parent-firm level. 
Table 4

Related functional experience and inherited agglomeration effects

\begin{tabular}{|c|c|c|c|c|c|c|}
\hline Dependent variable: information ratio & $\begin{array}{r}(1) \\
\text { OLS }\end{array}$ & & $\begin{array}{r}(2) \\
\text { P-score }\end{array}$ & & $\begin{array}{r}(4) \\
\text { CEM }\end{array}$ & \\
\hline $\begin{array}{l}\text { PARENT_CENTER } x \text { Manager's previous } \\
\text { job in investment management }\end{array}$ & $\begin{array}{r}0.08 \\
(0.04)\end{array}$ & $*$ & $\begin{array}{r}0.11 \\
(0.06)\end{array}$ & $* *$ & $\begin{array}{r}0.11 \\
(0.06)\end{array}$ & $*$ \\
\hline Parent firm in NYC/London (PARENT_CENTER) & $\begin{array}{r}0.06 \\
(0.04)\end{array}$ & & $\begin{array}{r}0.09 \\
(0.07)\end{array}$ & & $\begin{array}{r}0.09 \\
(0.07)\end{array}$ & \\
\hline Manager's previous job in investment mgmt. & $\begin{array}{r}-0.07 \\
(0.05)\end{array}$ & & $\begin{array}{r}-0.04 \\
(0.06)\end{array}$ & & $\begin{array}{r}-0.08 \\
(0.06)\end{array}$ & \\
\hline Hedge fund in NYC/London (HF_CENTER) & $\begin{array}{r}0.03 \\
(0.03)\end{array}$ & & $\begin{array}{r}0.06 \\
(0.04)\end{array}$ & $*$ & $\begin{array}{r}0.05 \\
(0.04)\end{array}$ & \\
\hline $\begin{array}{l}\text { HF_CENTER x Manager's previous job } \\
\text { in investment management }\end{array}$ & $\begin{array}{r}0.02 \\
(0.04)\end{array}$ & & $\begin{array}{r}-0.01 \\
(0.05)\end{array}$ & & $\begin{array}{r}0.02 \\
(0.05)\end{array}$ & \\
\hline Other controls & Y & & Y & & Y & \\
\hline Manager's SAT score quintile dummies & Y & & Y & & Y & \\
\hline Manager's graduate degree dummies & Y & & Y & & Y & \\
\hline 7 parent firm bulge bracket dummies & Y & & Y & & Y & \\
\hline $\begin{array}{l}\mathrm{N} \\
\mathrm{R}^{2}\end{array}$ & $\begin{array}{r}658 \\
0.12\end{array}$ & & $\begin{array}{r}466 \\
0.15\end{array}$ & & $\begin{array}{r}423 \\
0.14\end{array}$ & \\
\hline
\end{tabular}

* significant at the $10 \%$ level; ** significant at the 5\% level; *** significant at the $1 \%$ level; Standard errors (in parentheses) are robust and clustered at the parent-firm level.

"Other controls" are as in Table 3: SIC6, RANKED, Parent Tobin's Q, Hedge fund within 100 miles of NYC/London, Hedge fund age, Log avg. number of funds, size, the constant, and the missing data dummies.

Table 5

Mechanisms and Founder effects

\begin{tabular}{|c|c|c|c|c|c|}
\hline $\begin{array}{l}\text { Dependent variable: information ratio } \\
\text { Sub-sample }\end{array}$ & $\begin{array}{r}(1 a) \\
\text { Direct } \\
\text { investment } \\
\text { funds }\end{array}$ & & $\begin{array}{r}\text { (1b) } \\
\text { Fund- } \\
\text { of-funds }\end{array}$ & $\begin{array}{r}\text { (2) } \\
\text { Founders } \\
\text { only }\end{array}$ & \\
\hline $\begin{array}{l}\text { Parent firm in NYC or London } \\
\text { (PARENT_CENTER) }\end{array}$ & $\begin{array}{r}0.13 \\
(0.04)\end{array}$ & $* * *$ & $\begin{array}{r}0.07 \\
(0.08)\end{array}$ & $\begin{array}{r}0.09 \\
(0.04)\end{array}$ & $* *$ \\
\hline Hedge fund in NYC or London (HF_CENTER) & $\begin{array}{r}0.05 \\
0.03)\end{array}$ & $*$ & $\begin{array}{r}0.06 \\
(0.05)\end{array}$ & $\begin{array}{r}0.07 \\
(0.03)\end{array}$ & $* *$ \\
\hline Other controls & Y & & Y & $\mathrm{Y}$ & \\
\hline Manager's SAT score quintile dummies & Y & & Y & Y & \\
\hline Manager's graduate degree dummies & Y & & $\mathrm{Y}$ & $\mathrm{Y}$ & \\
\hline 7 parent firm bulge bracket dummies & Y & & Y & Y & \\
\hline $\mathrm{N}$ & 478 & & 180 & 373 & \\
\hline $\mathrm{R}^{2}$ & 0.14 & & 0.34 & 0.15 & \\
\hline
\end{tabular}

* significant at the $10 \%$ level; ** significant at the 5\% level; *** significant at the $1 \%$ level

Standard errors (in parentheses) are robust and clustered at the parent-firm level.

"Other controls" are as in Table 3: SIC6, RANKED, Parent Tobin's Q, Hedge fund within 100 miles of NYC/London, Hedge fund age, Log avg. number of funds, size, the constant, and the missing data dummies. 